\title{
Parenting stress, social support, self-compassion, and parenting practices among mothers of children with ASD and ADHD
}

\author{
Yulina Eva Riany, ${ }^{1 *}$ Ayu Ihsana ${ }^{2}$ \\ ${ }^{1}$ Parenting and Family Support Centre, The University of Queensland, Brisbane, Queensland - Australia, \\ ${ }^{2}$ Faculty of Human Ecology, Institut Pertanian Bogor, Bogor - Indonesia
}

\begin{abstract}
Parenting of children with Autism Spectrum Disorder (ASD) and Attention Deficit Hyperactivity Disorder (ADHD) faces many challenges and often causes stress amongst parents. This study aims sto analyze the differences in parenting stress, perceptions of social support, self-compassion, and parenting practices in groups of mothers of ASD children and of ADHD children. The Parental Stress Scale, the Multidimensional Scale of Perceived Social Support, the Self-compassion Scale, and the Parent Construct were used to collect the study data. The survey was taken voluntarily online by 34 mothers of ASD children (52\%) and 31 mothers of ADHD children (48\%). MANOVA and regression analysis were performed to test the study hypothesis. The results show that there was no significant difference in parenting stress $(\mathrm{F}=0.04, \mathrm{p}>.05)$, social support $(\mathrm{F}=0.16-0.31, \mathrm{p}>.05)$, self-compassion $(\mathrm{F}=0.01-1.46, \mathrm{p}>.05)$, and parenting practices $(\mathrm{F}=0.04-2.29, \mathrm{p}>.05)$ between the two groups. Parenting stress had a significant negative effect on parenting practices in both groups studied $(\mathrm{p}<.05)$. The study provides an overview of the parenting practices of parents of ASD and ADHD children in Indonesia.
\end{abstract}

Keywords: ADHD; ASD; parenting practices; parenting stress; self-compassion; social support

\begin{abstract}
Abstrak: Pengasuhan anak dengan Autism Spectrum Disorder (ASD) dan Attention Deficit Hyperactivity Disorder (ADHD) penuh dengan tantangan dan seringkali membuat orangtua mengalami stres. Penelitian ini bertujuan untuk menganalisis perbedaan stres pengasuhan, persepsi dukungan sosial, self-compassion, dan praktik pengasuhan pada kelompok Ibu anak ASD dan kelompok Ibu anak ADHD. Skala Parental stress scale, the Multidimensional Scale of Perceived Social Support, SelfCompassion Scale, dan Parent Construct digunakan untuk mengumpulkan data penelitian ini. Survei diikuti secara voluntir oleh 34 ibu anak ASD (52\%) dan 31 ibu anak ADHD (48\%) secara daring. Analisis MANOVA dan regresi dilakukan untuk menguji hipotesis pada penelitian ini. Hasil penelitian menunjukkan bahwa tidak ada perbedaan signifikan pada stres pengasuhan $(\mathrm{F}=0,04, \mathrm{p}>0,05)$, dukungan sosial $(\mathrm{F}=0,16$ - 0,31, $\mathrm{p}>0,05)$, self-compassion $(\mathrm{F}=0,01-1,46, \mathrm{p}>0,05)$, dan praktik pengasuhan $(\mathrm{F}=0,04-2,29, \mathrm{p}>0,05)$ antar dua kelompok dalam penelitian ini. Stres pengasuhan memiliki pengaruh signifikan terhadap praktik pengasuhan yang bersifat negatif pada kedua kelompok yang diteliti $(\mathrm{p}<0,05)$. Penelitian ini memberikan gambaran tentang praktik pengasuhan pada orang tua anak ASD dan ADHD di Indonesia Indonesia.
\end{abstract}

Kata Kunci: ADHD; ASD; praktek pengasuhan; stress pengasuhan; self-compassion; dukungan sosial "Corresponding Author: Yulina Eva Riany (y.riany@uq.edu.au), Parenting and Family Support Centre, The University of Queensland,
19/13 Upland Rd, St Lucia QLD 4067, Brisbane, Queensland - Australia. 


\section{Introduction}

A substantial body of research has indicated that parenting to be a significant factor for the positive development of children with special needs. Parenting is closely related to a family's ability to provide time, attention, and support to meet physical, mental, and social needs during the child's growth. Parenting practice has been defined as specific goal-oriented childcare behaviours (Lee etal., 2006).

Although some parenting typologies have been identified, parenting is often categorized into two types, positive and negative (Simons, et al, 1990). Positive parenting is characterized as parenting with a high level of supports towards child development (Simons et al., 1990). Parents with positive care are more likely to spend a high amount of time with children, being supportive, responsive, and sensitive. On the other hand, negative parenting is characterized by high levels of control which may include verbal hostility and physical punishment (Gulley et al., 2014; Senese et al., 2021). Parents with negative parenting care tend to use hard discipline and squabbling parenting (Patterson, 1986).

Parenting children with disabilities, particularly parenting among children with Autism Spectrum Disorder (ASD) and Attention Deficit Hyperactivity Disorder (ADHD), often involves a high level of parenting stress (Boyd, 2002; Riany, 2016; Schieve et al., 2007). Autism Spectrum Disorder (ASD) refers to a continuous disturbance in interaction and communication, limited and repetitive behaviour from an early age, and has disturbing symptoms in everyday life (American Psychological Association, 2013). Meanwhile, Attention Deficit Hyperactivity Disorder (ADHD) is defined as a disorder with high levels of impulsivity, inattention, and activity symptoms (APA, 2013). The characteristics of children with ASD and ADHD with significant limitations on intellectual functioning and adaptive behaviours, including conceptual, social, and practical skills, have been indicated as the strong predictor for parenting stress (Pimentel et al., 2011; Platt et al,, 2018). A study conducted by Ma, Lai, and Lo (2016) found that mothers, single parents, older people, parents with low perceptions of social support, and parents with knowledge that low on symptoms of children, especially ASD and ADHD children, were found to be the highest parenting stress. These conditions lead parents found challenges in fulfilling their parental roles (Pimentel etal., 2011).

Although parental stress is associated with parenting challenges among families with ASD and ADHD, the relations between parenting stress and these two types of disorders are inconsistent. A research conducted among parents of neurodevelopmental disorders indicated that parents of children with ASD reported the highest level of stress compared to parents with down syndrome, Tourette syndrome, and ADHD (Craig et al., 2016). This parenting stress is due to more significant behaviour problems among children with ASD and parents' limited ability to manage their children's negative behaviours (Phelps et al, 2009). The parenting stress experienced by parents of children with ASD often lead them to face difficulties in regulations and implementing positive parenting practice compared to those without children with ASD (Riany et al., 2017).

However, another study has reported that parents of children with ADHD often exhibit more challenges in parenting contributing to stress than parents of children without ADHD (Schroeder \& Kelley, 2009). The study reported that parents of 
children with ADHD tend to be more demanding in their interactions but poorer understanding of their child's learning abilities. McLaughlin and Harrison (2006) also found that higher disruptive behaviour among children with ADHD led to less effective parenting practices conducted by the parents of children with ADHD than those without ADHD.

Availability of support also influences the way how their parents raise children with ASD and ADHD. Studies found that parenting children with ASD and ADHD are challenging due to a lack of social supports (Phelps et al., 2009; Riany et al., 2019). Parents of children with ASD and ADHD often perceive rejection and inferiority towards society for having children with disabilities, particularly children with ASD (Anggraini, 2013; Riany et al., 2016). Accordingly, parents tend to display uncontrolled negative emotions daily raising their children (Wijaya, 2015).

Studies have found that parenting stress is significantly reduced by social support (Hidayati, 2011; Theule et al., 2011). Social support refers to relatives or family members' physical and psychological comfort (Adicondro \& Purnamasari, 2011). According to Taylor et al. (2015), social support is a psychological resource bound to contributing positively to practising parenting. Research indicated strong links between parenting stress and social support in parenting children with developmental disabilities (Gupta, 2007; Riany et al., 2017). Social support has been found to decrease parental stress through increasing physical well-being and quality of family life (Hidayati, 2011). Also, accessibility and social support can reduce stress, depression, and anxiety for mothers of children with developmental disabilities, such as ASD or
ADHD, and increase life satisfaction (Meadan et al., 2010).

Previous research by Riany et al. (2017) showed significant differences in aspects of parental social support in children with ASD and without ASD. The research showed that parents with ASD children have lower levels of social support than parents with children without ASD. Parents with ASD children have more informal support from the help of family members, friends, neighbours, the immediate environment, and care that tends to be positive in parenting. Similarly, the intense relations of social supports in reducing parenting stress also implies among parents of children with ADHD so that social support is an essential factor in parenting practices (McLaughlin \& Harrison, 2006).

Despite social supports, the research found that self-compassion was also significant factors in reducing parenting stress. Self-compassion is defined as the management of emotions by emotionally positive self-attitude to protect themselves from harmful things in self-assessment, isolation, and contemplation in the form of depression (Neff, 2003). Management of emotions or self-compassion effectively avoids stress, which is divided into three aspects, including mindfulness, common humanity, and kindness-restraining one's painful thoughts and feelings in mindfulness, seeing one's mistakes as part of a more significant human condition and experience (common humanity), and being kind and understanding of oneself in terms of pain or failure (kindness). Self-compassion is a valuable coping resource. Research conducted by Allen and Leary (2010) shows that self-compassion has an essential role in the coping process. The relationship between self-compassion and coping 
shows that self-compassion involves thinking about stressful situations that increase coping. Someone with a high level of self-compassion has reported sharing their problems with others for support (Allen \& Leary, 2010). Research conducted by Kristiana (2017) has indicated that self-compassion has a role in parenting stress experienced by mothers. The lower level of selfcompassion experienced, the higher level of parenting stress reported.

In parenting children with disabilities, parents' self-compassion is indicated by the parent's ability to implement effective strategies in dealing with problems. Self-compassion or management of self-emotions is an effort to manage negative emotions with full awareness. Therefore, self-compassion is shown to be successful in reducing personal anxiety and depression levels (Neff \& Germer, 2012). That is because self-compassion can improve the coping skills of parents (Kristiana, 2017). Research conducted by Neff and Faso (2014) shows that there is a positive relationship between selfcompassion and life satisfaction, hope and has a negative relationship with depression and parental stress.

Self-compassion has been found as an effective way of increasing parents' well-being and reducing the adverse effects of the severity of symptoms of children with ASD on the adaptability of parents (Neff \& Faso, 2014). Research conducted by Dehkordian et al. (2017) revealed that self-compassion influenced positive parenting of children with ADHD, explicitly holding one's mind and painful feelings (mindfulness) and seeing one's mistakes as part of the condition and experience of humans (sense of shared common humanity).
While extensive research focusing on parenting children with ASD and ADHD was conducted worldwide, research in this area is still limited in Indonesia. That is a reason to believe that parents of children with ASD and ADHD in Indonesia have limited knowledge and available information regarding the strategy to support the development of their children optimally (Gandasetiawan, 2009; Riany, 2021). Although in Indonesia, ASD and ADHD are perceived as the most severe types of developmental disorders due to challenging state children with ASD and ADHD (Khoirunnisyak et al., 2017), research on parenting stress, social support, self-compassion, and parenting practices among Indonesian parents of children with ASD and ADHD is still scarce.

According to Badan Pusat Statistik [BPS] (2013), approximately 66 million children aged 519 years were diagnosed with ASD in 2013. In 2016, the prevalence of children with ASD in Indonesia was 1-2 per 1000 children (Priherdityo, 2016). The number of children with ADHD also increases every year, with approximately $2-4 \%$ of Indonesia's total school children population (Tentama, 2012).

The present study investigates the parenting stress, social support, self-compassion, and parenting practices among Indonesian parents of children with ASD and ADHD in Indonesia. Specifically, this study aims to compare parenting stress, social support, self-compassion, and parenting practices experienced by parents with children with ASD and ADHD. This research also investigates the links among investigated variables and parenting practices among parents from both groups. It is hypothesised that parenting stress, social support, self-compassion, 
and parenting practice will differ between parents of children with ASD and children with ADHD. Also, it is hypothesised that parenting stress and social support will predict parenting practices among parents of children with ASD and parents of children with ADHD.

\section{Method}

\section{Participants}

Seventy-five parents of children with ASD and ADHD participated in this study. Only 65 parents completed the survey. Participants were all mothers with 34 mothers of children with ASD and 31 mothers of children with ADHD. The majority gender of children in this study were boys (79.5\%). The largest parental age group is in the early adult category (67.6\%), with an average age of 38 years. More than half of parents with ASD (84.3\%) and ADHD (61.3\%) children have completed their undergraduate education. Based on the parents' occupation, half of the respondents were housewives or unemployed (55.4\%). Almost all respondents are married (90.8\%). There was no significant difference in demographic characteristics between these two groups. Detailed participants' information is presented in Table 1.

\section{Procedures}

The first task of the study was to translate the instruments from English to Indonesian. The translation and back-translation process were used to develop the instrument used in this study (Brislin, 1970). This translation was conducted by the first author and other researchers in family studies not related to this research project. Translation into Indonesian using Ejaan yang Disempurnakan (EYD) or formal academic Indonesian. Corrections were made to resolve differences in the vocabulary and meanings of statements until an agreement was reached.

In collecting the data, potential participants in this study were approached using social media networks of parents of children with disabilities. Research information and participants' informed consent were distributed through social media (Facebookgroup and WhatsApp). Only those who were willing to participate in this study were presented the link to the survey. Those who clicked agree to participate on the link were directed to access the questionnaires of the study. Participants completed a set of google form questionnaires voluntarily.

\section{Measures}

Parental Stress Scale (PSS) was developed by Berry and Jones (1995). The PSS is a measure to assess the level of stress experienced by parents due to parenting. The Parental Stress Scale consists of 18 items that describe the parent-child relationship and the parent's feelings regarding their parenting. Both positive and negative items are included, which allows the instrument to assess stress by weighing the negative impact of parenting against the benefits it may provide. The questionnaire uses a-5 point Likert scale $(1=$ strongly disagree to $5=$ strongly agree). This questionnaire has shown validity and adequate internal consistency with Cronbach alpha coefficient of this sample is 0.83 . 
Table 1

Respondents Demographic Characteristics $(N=65)$

\begin{tabular}{|c|c|c|c|c|}
\hline \multirow{2}{*}{ Variables } & \multicolumn{2}{|c|}{$\operatorname{ASD}(N=34)$} & \multicolumn{2}{|c|}{$\operatorname{ADHD}(\mathrm{N}=31)$} \\
\hline & $\%$ & $\mathrm{~N}$ & $\%$ & $\mathrm{~N}$ \\
\hline $\begin{array}{l}\text { Maternal Age } \\
\text { Early adulthood ( } 18-40 \text { years old) } \\
\text { Middle adulthood }(41-60 \text { years old }) \\
\text { Elderly }(>60 \text { years old) }\end{array}$ & $\begin{array}{l}67.6 \\
32.4 \\
0\end{array}$ & $\begin{array}{l}23 \\
11 \\
0\end{array}$ & $\begin{array}{l}71.0 \\
29.0 \\
0\end{array}$ & $\begin{array}{l}22 \\
9 \\
0\end{array}$ \\
\hline $\begin{array}{l}\text { Highest Level of Education } \\
\text { Elementary Education } \\
\text { Secondary Education } \\
\text { Tertiary Education }\end{array}$ & $\begin{array}{l}2.9 \\
11.8 \\
84.3\end{array}$ & $\begin{array}{l}1 \\
4 \\
29\end{array}$ & $\begin{array}{l}3.2 \\
35.5 \\
61.3\end{array}$ & $\begin{array}{l}1 \\
11 \\
19\end{array}$ \\
\hline $\begin{array}{l}\text { Working Status } \\
\text { Employed } \\
\text { Unemployed }\end{array}$ & $\begin{array}{l}50.0 \\
50.0\end{array}$ & $\begin{array}{l}17 \\
17\end{array}$ & $\begin{array}{l}38.7 \\
61.3\end{array}$ & $\begin{array}{l}12 \\
19\end{array}$ \\
\hline $\begin{array}{l}\text { Marital Status } \\
\text { Married } \\
\text { Divorced } \\
\text { Widowed } \\
\text { Single }\end{array}$ & $\begin{array}{l}88.2 \\
5.9 \\
5.9 \\
0\end{array}$ & $\begin{array}{l}30 \\
2 \\
2 \\
0\end{array}$ & $\begin{array}{l}93.5 \\
3.2 \\
0 \\
3.2\end{array}$ & $\begin{array}{l}29 \\
1 \\
0 \\
1\end{array}$ \\
\hline $\begin{array}{l}\text { Family Category } \\
\text { Small family ( } \leq 4 \text { persons) } \\
\text { Medium family (5-7 persons) } \\
\text { Big family ( } \geq 8 \text { persons) }\end{array}$ & $\begin{array}{l}70.6 \\
29.4 \\
0\end{array}$ & $\begin{array}{l}24 \\
10 \\
0\end{array}$ & $\begin{array}{l}61.3 \\
38.7 \\
0\end{array}$ & $\begin{array}{l}19 \\
12 \\
0\end{array}$ \\
\hline $\begin{array}{l}\text { Monthly Income/capita (IDR) }{ }^{*_{a}, \mathrm{~b}} \\
\quad<\text { IDR } 425.250 \\
\quad \geq \text { IDR } 425.250\end{array}$ & $\begin{array}{l}11.8 \\
88.2\end{array}$ & $\begin{array}{l}1.664 .215^{c} \\
4 \\
30\end{array}$ & $\begin{array}{l}10.8 \\
89.2\end{array}$ & $\begin{array}{l}2.132 .342 \\
7 \\
24\end{array}$ \\
\hline $\begin{array}{l}\text { Child Gender } \\
\text { Male } \\
\text { Female }\end{array}$ & $\begin{array}{l}79.4 \\
20.6\end{array}$ & $\begin{array}{l}27 \\
7\end{array}$ & $\begin{array}{l}80.6 \\
19.4\end{array}$ & $\begin{array}{l}25 \\
6\end{array}$ \\
\hline $\begin{array}{l}\text { Variables } \\
\text { Maternal Age }\end{array}$ & $\begin{array}{l}\text { Mean } \\
37.65\end{array}$ & $\begin{array}{l}\text { SD } \\
6.37\end{array}$ & $\begin{array}{l}\text { Mean } \\
36.42\end{array}$ & $\begin{array}{l}\text { SD } \\
6.25\end{array}$ \\
\hline Child Age & 9.12 & 4.26 & 6.61 & 3.08 \\
\hline
\end{tabular}

aSecondary data, Indonesia National Statistic (Badan Pusat Statistik [BPS], 2019) Indonesia's national poverty line in March 2019, bIndonesian Rupiah, cAverage income (IDR/person/capita)

The Multidimensional Scale of Perceived Social Support (MSPSS) was developed by (Zimet, et al., 1988). The questionnaire consists of 12 statement items and three subscales: Family, Friends, and Significant Others. Each subscale consists of four statements. The MPSS employs a7 points Likert scale with seven scores (1 = strongly disagree to 7 = strongly agree). The instrument has been widely applied, with satisfactory reliability and validity. In this sample, the Cronbach's alpha coefficients for Family, Friends, and Significant Others were .87, .85, and .91 , respectively.
Self-Compassion Scale (SCS) was developed by Neff (2003). This questionnaire consists of 13 items (5 items measure aspects of self-kindness, four items measure aspects of humanity, four items measure aspects of mindfulness). The answer scale uses a-5 points Likert scale with the description 1 = never to 5 = always. This questionnaire has a Cronbach's alpha coefficient for the self-kindness aspect of .77, a common humanity aspect of .80, and mindfulness aspects of .75 .

Parent Constructs (PC) was developed by Stormshak, Bierman, McMahon, and Lengua 
(2000). The questionnaire was employed to measure parenting practices that mothers do for their children. This questionnaire consists of 42 statement items (10 items measure aspects of warmth/involvement, nine items measure aspects of consistency, 12 items measure aspects of hard discipline, three items measure aspects of spanking, and eight items measure aspects of physical aggression). This instrument comes from a combination of three instruments, including Parent Questionnaire (PQ) (Strayhorn and Weidman, 1988), a 19-items measure using a- 4 points Likert scale $(0=$ never to $4=$ every day), Parenting Practices Inventory (PPI) (Conduct Problems Prevention Research Group (CPPRG), 1992), a seven-items instrument using a-3 points Likert scale ( $0=$ never to $3=$ often), and Conflict Tactics Scale (CTS) (Straus, 1989), a-16 items questionnaire with a- 6 points Likert scale $(0=$ never to $6=$ always). The PQ has aspects of warmth/ involvement, consistency, and hard discipline while the PPI consists of consistency and hard discipline subscales. CTS has aspects of hard discipline, spanking and physical aggression. This questionnaire has the Cronbach's alpha coefficient on each aspect of warmth, consistency, hard discipline, spanking, and physical aggression of $0.73,0.74,0.72,0.73,0.73$, and 0.73 .

\section{Statistical Analysis}

IBM SPSS Statistic 25 was used in data analyses. Analysis of the data used on each variable will be adjusted to the purpose of the study, including independent sample t-test and MANOVA used to identify differences in child characteristics, maternal characteristics, parenting stress, social support, self-compassion, and parenting practices based on the type of child disorder (ASD and ADHD). Pearson correlation analysis was used to determine the relationship between child characteristics, maternal characteristics, parenting stress, social support, self-compassion, and parenting practices. Regression analyses were used to analyse the impact of child characteristics and maternal characteristics, parenting stress, social support, self-compassion, and parenting practices. Analyses were performed to ensure there were no violations of the assumptions of normality, multi-collinearity, auto-correlation, and heteroscedasticity, before running hierarchical multiple regression analyses to test the hypotheses.

\section{Results}

MANOVA revealed no significant difference in parenting stress, social support, self-compassion, and parenting practice between Indonesian parents of children with ASD and children with $\operatorname{ADHD}, \mathrm{F}(1,64)=0.89, \mathrm{p}=.57$, partial $\eta 2=.19$. In this study, parents from both groups reported comparable levels of parenting stress, perception of social supports, and perception of parenting practices (see Table 2).

The correlation analyses indicated that parenting stress was negatively correlated to social support (from partner and family), selfcompassion, and positive parenting practice for both groups (Table 3). Besides, parenting stress was significantly related to negative parenting practices among mothers of children with ASD and children with ADHD. Parental age was found to link with parental stress. The analyses also found that Family supports was positively correlated with two dimensions of the positive parenting (Warmth and Consistency subscales) and negatively linked to three dimensions of the negative parenting (Punitive Discipline, Spanking, and Physical Aggression) subscales. 
Table 2

Means (SD) and MANOVA Results of Parents of a Child with ASD and Parents of a Child with ADHD

\begin{tabular}{|c|c|c|c|c|c|c|c|}
\hline \multirow[t]{2}{*}{ Variables } & \multicolumn{2}{|c|}{$\operatorname{ASD}(\mathrm{N}=34)$} & \multicolumn{2}{|c|}{$\begin{array}{l}\text { ADHD } \\
(\mathrm{N}=31)\end{array}$} & \multirow[t]{2}{*}{$\mathrm{F}(\mathrm{df})$} & \multirow[t]{2}{*}{$\mathrm{p}$} & \multirow[t]{2}{*}{ Partial $\eta^{2}$} \\
\hline & M & SD & M & SD & & & \\
\hline Parenting Stress & 2.25 & 0.49 & 2.28 & 0.58 & $0.04(1.65)$ & .85 & .001 \\
\hline \multicolumn{8}{|l|}{ Social Support } \\
\hline Partner & 5.42 & 1.40 & 5.59 & 1.41 & $0.24(1.65)$ & .63 & .004 \\
\hline Family & 5.33 & 1.34 & 5.18 & 1.41 & $0.16(1.65)$ & .69 & .003 \\
\hline Friends & 4.82 & 1.33 & 4.61 & 1.62 & $0.31(1.65)$ & .58 & .005 \\
\hline \multicolumn{8}{|l|}{ Self-compassion } \\
\hline Self-Kindness & 3.92 & 0.71 & 3.70 & 0.77 & $1.46(1.65)$ & .23 & .023 \\
\hline Common Humanity & 4.02 & 0.69 & 4.15 & 0.45 & $0.77(1.65)$ & .38 & .012 \\
\hline Mindfulness & 3.95 & 0.60 & 3.94 & 0.58 & $0.01(1.65)$ & .94 & .00 \\
\hline \multicolumn{8}{|l|}{ Parenting practice } \\
\hline Warmth & 3.02 & 0.48 & 2.98 & 0.54 & $0.09(1.65)$ & .77 & .001 \\
\hline Consistency & 2.39 & 0.42 & 2.44 & 0.42 & $0.23(1.65)$ & .63 & .004 \\
\hline Harsh discipline & 1.07 & 0.54 & 1.20 & 0.76 & $0.63(1.65)$ & .43 & .00 \\
\hline Smacking & 0.25 & 0.37 & 0.19 & 0.33 & $2.29(1.65)$ & .14 & .036 \\
\hline Physical aggression & 0.42 & 0.48 & 0.45 & 0.64 & $0.04(1.65)$ & .85 & .001 \\
\hline
\end{tabular}

While support from Significant Others was not correlated with positive parenting, it was negatively associated with negative parenting practice among parents from both groups (Table 3). The correlation analyses found that social supports was negatively linked to self-compassion and positively correlated with positive parenting among mothers from both groups. A significant negative relationship between social support and positive parenting practice was only found among mothers of children with ADHD (Table 3). A strong correlation between self-compassion and social supports and positive parenting for both groups. A negative link between self-compassion and negative parenting practice was only found among mothers of children with ADHD (Table 3).

In explaining positive parenting practice among mothers of children with ASD, $28 \%$ of the total variance was explained $F(1,34)=2.19 p=$ .06). No variable contributed uniquely to the variance related to positive parenting among mothers of children with ASD in the final model
(Table 4). Regarding negative parenting practice among mothers of children with ASD, the model explained $17 \%$ of the total variance $F(1,34)=1.62$ $\mathrm{p}=.16)$. Similarly, there is no unique variable identified to explain the final model of the negative parenting practice among mothers of children with ASD (Table 4).

Regression analyses performed to explain positive parenting practice among mothers of children with ADHD indicated that $43 \%$ of the total variance was explained $\mathrm{F}(1,31)=3.07 \mathrm{p}=$ .02) (Table 4). The model indicated that parenting stress and social supports as unique variables to contribute to the model explaining the positive parenting practices among mothers of children with $\mathrm{ADHD}$. In explaining the negative parenting practice among mothers of children with ADHD, $52 \%$ of the total variance explained $F(1,31=3.93$ $\mathrm{p}<.01$ ) (Table 4). The model indicated that marital status and parenting stress as the unique factors contributed to the negative parenting practice among parents of children with ADHD. 
Table 3

Results of Correlational Analyses of Relationships Between Stress, Social Support, Self-Compassion, Parenting Practices, and Demographics (N=65)

\begin{tabular}{|c|c|c|c|c|c|c|c|c|c|}
\hline \multirow{2}{*}{ Group } & \multirow{2}{*}{ Variables } & \multirow{2}{*}{ PS } & \multirow{2}{*}{ SS } & \multirow{2}{*}{ SC } & \multicolumn{5}{|c|}{$\mathrm{PP}$} \\
\hline & & & & & 1 & 2 & 3 & 4 & 5 \\
\hline \multirow[t]{21}{*}{ ASD } & Child age & $-.36^{*}$ & -.02 & .03 & -.01 & .28 & -.13 & -.07 & -.13 \\
\hline & Gender & .09 & .13 & .21 & .16 & -.06 & -.02 & -.28 & -.23 \\
\hline & Maternal age & $-.42^{*}$ & .20 & .21 & .19 & $.38^{*}$ & -.27 & -.29 & -.21 \\
\hline & Level of education & $.36^{*}$ & -.17 & -.14 & -.03 & -.20 & .19 & .16 & .06 \\
\hline & Work status & .25 & .03 & .09 & .11 & $-.42^{*}$ & .33 & .135 & .07 \\
\hline & Marital status & -.06 & $-.45^{* *}$ & .07 & .01 & .01 & -.08 & -.01 & -.24 \\
\hline & Parenting stress (PS) & 1 & & & & & & & \\
\hline & Social Support (SS) & -.28 & 1 & & & & & & \\
\hline & Spouse & $-.34^{*}$ & & $.51^{* *}$ & $.34^{*}$ & .30 & -.25 & -.22 & -.34 \\
\hline & Family & $-.42^{*}$ & & $.58^{* *}$ & .29 & .18 & -.09 & -.13 & -.16 \\
\hline & Friends & .12 & & .16 & .15 & -.26 & -.09 & -.20 & -.17 \\
\hline & Self-Compassion (SC) & $-.38^{*}$ & $.55^{* *}$ & 1 & & & & & \\
\hline & Self-kindness & $-.38^{*}$ & .21 & & .29 & $.49^{* *}$ & -.18 & -.11 & -.06 \\
\hline & Mindfulness & $-.27^{*}$ & $.54^{* *}$ & & .28 & .17 & -.19 & -.18 & -.21 \\
\hline & Positive parenting & $-.60^{* *}$ & $.31^{*}$ & $.51^{* *}$ & & & & & \\
\hline & Warmth (1) & -.29 & $.35^{*}$ & $.41^{*}$ & 1 & & & & \\
\hline & Consistency (2) & $-.62^{* *}$ & .10 & $.34^{*}$ & .10 & 1 & & & \\
\hline & Negative parenting & $.41^{*}$ & -.28 & -.13 & & & & & \\
\hline & Harsh Discipline (3) & $.42^{*}$ & -.19 & -.13 & -.29 & $-.56^{* *}$ & 1 & & \\
\hline & Spanking (4) & $.39^{*}$ & -.27 & -.09 & $-.41^{*}$ & -.34 & $.60^{* *}$ & 1 & \\
\hline & Aggression (5) & .27 & -.29 & -.12 & -.27 & -.32 & $.64^{* *}$ & $.74^{* *}$ & \\
\hline \multirow[t]{22}{*}{ ADHD } & Child age & -.07 & .09 & .01 & .03 & -.14 & -.01 & .05 & -.06 \\
\hline & Gender & -.05 & -.15 & .12 & -.29 & -.17 & -.12 & -.14 & -.09 \\
\hline & Maternal age & -.12 & .22 & .15 & .02 & -.05 & .04 & .07 & .06 \\
\hline & Level of education & .02 & .04 & .06 & .16 & .06 & -.07 & -.19 & -.07 \\
\hline & Work status & -.12 & .08 & .19 & .02 & .21 & $-.46^{* *}$ & -.22 & -.32 \\
\hline & Marital status & .04 & .05 & .03 & .09 & .14 & -.26 & $-.37 *$ & $-.44^{*}$ \\
\hline & Parenting stress (PS) & 1 & & & & & & & \\
\hline & Social Support (SS) & $-.59 * *$ & 1 & & & & & & \\
\hline & Spouse & $-.61^{* *}$ & & $.53^{* *}$ & .35 & .16 & $-.47^{* *}$ & -.27 & $-.42 *$ \\
\hline & Family & $-.44^{*}$ & & .31 & .12 & -.08 & -.27 & .06 & .02 \\
\hline & Friends & $-.44^{*}$ & & $.47^{* *}$ & .17 & .05 & $-.42^{*}$ & -.21 & -.16 \\
\hline & Self-Compassion (SC) & $-.59 * *$ & $.52^{* *}$ & 1 & & & & & \\
\hline & Self-kindness & $-.59^{* *}$ & $.61^{* *}$ & & .24 & .24 & $-.48^{* *}$ & $-.56^{* *}$ & $.52^{* *}$ \\
\hline & Humanity & $-.34^{*}$ & .26 & & -.05 & $.39 *$ & -.33 & $-.46^{* *}$ & -.33 \\
\hline & Mindfulness & $-.55^{* *}$ & $.36^{*}$ & & $.36^{*}$ & $.42^{*}$ & $-.54^{* *}$ & $-.57 * *$ & -.33 \\
\hline & Positive parenting & $-.58^{* *}$ & .23 & $.39^{*}$ & & & & & \\
\hline & Warmth (1) & $-.55^{* *}$ & .25 & .24 & 1 & & & & \\
\hline & Consistency (2) & -.31 & .08 & $.37^{*}$ & .11 & 1 & & & \\
\hline & Negative parenting & $.63^{* *}$ & $-.36^{*}$ & $-.58^{* *}$ & & & & & \\
\hline & Harsh Discipline (3) & $.66^{* *}$ & $-.45^{*}$ & $-.52^{* *}$ & -.25 & $-.48^{* *}$ & 1 & & \\
\hline & Spanking (4) & $.43^{*}$ & -.16 & $-.61^{* *}$ & -.29 & .24 & $.51^{* *}$ & 1 & \\
\hline & Aggression (5) & $.49^{* *}$ & -.23 & $-.47^{* *}$ & -.16 & -.36 & $.76^{* *}$ & $.66^{* *}$ & 1 \\
\hline
\end{tabular}

${ }^{*} \mathrm{p}<.05,{ }^{* *} \mathrm{p}<.01$ 
Table 4

Results of Regression Analyses of Impact Stress, Social Support, Self-Compassion on Parenting Practices

\begin{tabular}{|c|c|c|c|c|c|c|c|}
\hline \multirow{2}{*}{ Parenting Practices } & \multirow{2}{*}{ Variables } & \multicolumn{3}{|l|}{ ASD } & \multicolumn{3}{|c|}{ ADHD } \\
\hline & & $\mathrm{B}$ & $\beta$ & Sig & $\mathrm{B}$ & $\beta$ & Sig \\
\hline \multirow{12}{*}{$\begin{array}{l}\text { Positive Parenting } \\
\text { (Warmth and Consistency) }\end{array}$} & Child age (years) & -.01 & -.08 & .73 & -.01 & -.11 & .59 \\
\hline & Gender & .00 & .01 & .99 & -.44 & -.49 & .06 \\
\hline & Maternal age (years) & .01 & .25 & .28 & .01 & .05 & .81 \\
\hline & Lev Education & .02 & .13 & .50 & .03 & .27 & .13 \\
\hline & Work status & -.07 & -.11 & .54 & -.09 & -.12 & .46 \\
\hline & Marital Status & -.04 & -.04 & .85 & -.16 & -.11 & .49 \\
\hline & Parenting stress (PS) & -.27 & -.40 & .06 & -.42 & -.68 & $.00^{* *}$ \\
\hline & Social Support (SS) & .00 & .01 & .99 & .11 & .38 & $.06^{*}$ \\
\hline & Self-Compassion (SC) & .21 & .34 & .12 & .21 & .31 & .14 \\
\hline & Adj. $R^{2}$ & .28 & & & .43 & & \\
\hline & $\mathrm{F}$ & 2.19 & & & 3.07 & & \\
\hline & Sig & .06 & & & .02 & & \\
\hline \multirow{12}{*}{$\begin{array}{l}\text { Negative Parenting } \\
\text { (Harsh Discipline, Spanking, } \\
\text { Physical Aggression) }\end{array}$} & Child age (years) & .00 & .00 & .97 & -.01 & -.01 & .72 \\
\hline & Gender & -.21 & -.21 & .23 & -.05 & -.03 & .79 \\
\hline & Maternal age (years) & -.01 & -.21 & .41 & .01 & .09 & .66 \\
\hline & Lev education (years) & -.01 & -.07 & .75 & .02 & .13 & .41 \\
\hline & Work status & -.00 & -.00 & .99 & -.29 & -.29 & .07 \\
\hline & Marital Status & .23 & .19 & .39 & .75 & .38 & $.02 *$ \\
\hline & Parenting stress (PS) & .33 & .39 & .09 & .35 & .41 & $.03 *$ \\
\hline & Social Support (SS) & -.09 & -.22 & .40 & -.02 & -.04 & .81 \\
\hline & Self-Compassion (SC) & .12 & .15 & .51 & -.32 & -.35 & .08 \\
\hline & Adj. R2 & .17 & & & .52 & & \\
\hline & $\mathrm{F}$ & 1.62 & & & 3.93 & & \\
\hline & Sig & .16 & & & .00 & & \\
\hline
\end{tabular}

${ }^{*} \mathrm{p}<.05,{ }^{* *} \mathrm{p}<.01$

\section{Discussion}

The present study's first aim was to investigate the differences in parenting stress, social support, self-compassion, and parenting practice that would differ between parents of children with ASD and children with ADHD. Results indicated no significant difference regarding level stress of mothers of children with ASD children and mothers of children with ADHD. The findings in the present study were not in line with the hypothesis predicting there would be differences in investigated variables between participants from the two groups. The study results also did not support the previous study indicating that parents of children with ASD have a higher level of stress than parents of children with ADHD (Phelps et al., 2009) or another study finding that parents of children with ADHD reported higher levels of stress compared to mothers of children with ASD (Miranda et al., 2015). In this study, both mothers of children with ASD and mothers of children with ADHD have a high-stress level. Perhaps this similarity in parenting stress between the two groups is due to comparable social supports received by mothers from both groups. Mothers of children with ASD and mothers of children with ADHD in this study reported a high number of social supports from partners, families, and friends. Therefore, it is not surprising that there is no difference in parenting practices between mothers from the two groups reported.

Besides, it was hypothesised that parenting stress, social support, and self-compassion would predict parenting practices among parents of 
children with ASD and children with ADHD. Results indicated similar patterns of the associations of the observed variables between the two groups. Parenting stress was reported to link with social supports negatively, primarily supports from partner and family and selfcompassion among parents of children with ASD and parents of children with ADHD. Mothers of children with disabilities in the present study reported having a low level of parenting stress if they experienced a high level of supports, notably support from husbands and relatives. They also perceive a low level of stress once they have a high level of self-compassion in parenting their child with ASD and ADHD. Participants from both groups reported being more positive in parenting and less negative in parenting practice if they experienced a low level of parenting stress, high supports, and self-compassion in parenting.

In explaining parenting practice among mothers of children with ASD, no unique factor was found to contribute significantly in their parenting children with ASD. Among mothers of children with ADHD, parenting stress and social supports were reported to contribute significantly to the positive parenting practices, while marital status and parenting stress revealed as the unique factors to the negative parenting practice among parents of children with ADHD. The study's findings partially supported the hypothesis that parenting stress, social support, and selfcompassion would predict parenting practices among parents of children with ADHD. Indonesian mothers of children with $\mathrm{ADHD}$ reported that parenting stress and social supports contribute to their positive parenting practice, while marital relations and parenting stress contributed to their negative parenting practice. The study's findings supported the previous study indicating that parenting stress and social supports are factors to be significantly related to parenting practices towards children with disabilities (Gupta, 2007; Hidayati, 2011; Riany et al., 2019). In this study, Indonesian mothers who perceived more support and low parenting stress levels reported more positive parenting. On the other hand, mothers who experienced a low level of support from partners due to their single marital status experienced more negative in parenting their children with ADHD. This finding is in line with research conducted by (Taylor et al,, 2015), which shows that social support contributes positively to practising parenting practices.

While the findings of this study provide a snapshot of parenting children with ASD and ADHD in Indonesia, several limitations warrant consideration. Firstly, there is a limitation regarding sample size due to challenges in data collection. Due to the cultural beliefs of children with disabilities in Indonesia (see. Riany et al, 2016), parents of children with disabilities are more likely to be socially isolated and refused to participate in this study. A future study involving a bigger and more diverse sample size would expand the findings of the study. Secondly, no data on the severity of the children collected in this study. More specific information regarding the severity of disability would enrich how parenting practices may differ implemented. Lastly, in this research, most respondents were mothers; thus, fathers' views are not represented. Future research that employs multiple approaches to data collection, including information associated with characteristics of children with ASD and ADHD, may provide a more comprehensive picture, strengthening findings provided in this study. 


\section{Conclusion}

This study provides a picture of parenting practice among parents of children with ASD and ADHD in Indonesia, contributing to filling the gap to the limited available research in this field. As discussed earlier, the present study indicates no significant difference in parental stress between mothers of children with ASD children and mothers of children with ADHD. In this study, mothers from both groups have a high level of stress. Similarly, there is no difference between the two groups of mothers in social support, selfcompassion, and parenting practices.

The current study presents that parenting stress has been associated with social supports in which a low level of parenting stress is associated with a high level of support, which is applied to mothers from both groups. While among mothers of children with ASD, no unique factor is found to contribute significantly in their parenting children with ASD, parenting stress and social supports have been revealed as predictors for positive parenting practices among mothers of children with ADHD.

The present study has implications for parents, practitioners, and the Indonesian governments. The information presented in this study is essential to encourage all parties to focus and develop appropriate coping strategies to reduce the stress experienced by mothers of children with ASD and ADHD. Therefore, children with ASD and ADHD would implement positive parenting practices towards their children for positive child outcomes.]

\section{References}

Adicondro, N., \& Purnamasari, A. (2011). Efikasi diri, dukungan sosial keluarga dan self regulated learning pada siswa kelas VIII. Humanitas: Indonesian Psychological Journal, 8(1), 17. https://doi.org/10.26555/humanitas.v8i1.448

Allen, A. B., \& Leary, M. R. (2010). Self-compassion, stress, and coping. Social and Personality Psychology Compass, 4(2), 107-118. https://doi.org/10.1111/j.1751-9004.2009.00246.x

Anggraini, R. R. (2013). Persepsi orangtua terhadap anak berkebutuhan khusus (Deskriptif kuantitatif di SDLB N. 20 Nan Balimo Kota Solok). Jurnal Penelitian Pendidikan Khusus, 2(1), 258. https://doi.org/10.24036/jupe9510.64

Association, A. P. (2013). Diagnostic and statistical manual of mental disorders (DSM-5®). American Psychiatric Pub.

Badan Pusat Statistik. (2013). Autisme Indonesia. Bina Upaya Kesehatan Indonesia.

Badan Pusat Statistik. (2019). Profil kemisikinan Indonesia Maret tahun 2019. Badan Pusat Statistik.

Berry, J. O., \& Jones, W. H. (1995). The Parental Stress Scale: Initial psychometric evidence. Journal of Social and Personal Relationships, 12(3), 463-472. https://doi.org/10.1177/0265407595123009

Brislin, R. W. (1970). Back-translation for cross-cultural research. Journal of Cross-Cultural Psychology, 1(3), 185-216. https://doi.org/10.1177/135910457000100301

Conduct Problems Prevention Research Group (CPPRG). (1992). A developmental and clinical model for the prevention of conduct disorder: The FAST Track Program. Development and Psychopathology, 4(4), 509-527. https://doi.org/10.1017/S0954579400004855 
Craig, F., Operto, F. F., De Giacomo, A., Margari, L., Frolli, A., Conson, M., Ivagnes, S., Monaco, M., \& Margari, F. (2016). Parenting stress among parents of children with Neurodevelopmental Disorders. Psychiatry Research, 242,121-129. https://doi.org/10.1016/j.psychres.2016.05.016

Dehkordian, P., Hamid, N., Beshlideh, K., \& Mehrabizade Honarmand, M. (2017). The effectiveness of mindful parenting, social thinking and exercise on quality of life in ADHD children. International Journal of Pediatrics, 5(2), 4295-4302. https://doi.org/10.22038/ijp.2016.7900

Gandasetiawan, R. Z. (2009). Mengoptimalkan IQ \& EQ anak melalui metode sensomotorik. Libri.

Gupta, V. B. (2007). Comparison of parenting stress in different developmental disabilities. Journal of Developmental and Physical Disabilities, 19(4), 417-425. https://doi.org/10.1007/s10882-007-9060-x

Hidayati, N. (2011). Dukungan sosial bagi keluarga anak berkebutuhan khusus. Insan, 13(1), 13-20.

Khoirunnisyak, Akhyar, M., \& Gunarhadi. (2017). The development of sexual education learning model for autistic smp level based on socio-sexual behavior method in slb autis surakarta, indonesia. European Journal of Special Education Research, 2(3). https://doi.org/10.5281/zenodo.321553

Kristiana, I. F. (2017). Self-compassion dan stres pengasuhan ibu yang memiliki anak dengan hambatan kognitif. Jurnal Ecopsy, 4(1), 52-57.https://doi.org/10.20527/ecopsy.v4i1.3415

Lee, S. M., Daniels, M. H., \& Kissinger, D. B. (2006). Parental influences on adolescent adjustment: Parenting styles versus parenting practices. The Family Journal, 14(3), 253-259. https://doi.org/10.1177/1066480706287654

Ma, J. L. C., Lai, K. Y. C., \& Lo, J. W. K. (2016). Perceived social support in Chinese parents of children with attention deficit hyperactivity disorder in a Chinese context: Implications for social work practice. Social Work in Mental Health, 15(1), 28-46. https://doi.org/10.1080/15332985.2016.1159643

McLaughlin, D. P., \& Harrison, C. A. (2006). Parenting practices of mothers of children with ADHD: The role of maternal and child factors. Child and Adolescent Mental Health, 11(2), 82-88. https://doi.org/10.1111/j.1475-3588.2005.00382.x

Meadan, H., Halle, J. W., \& Ebata, A. T. (2010). Families with children who have autism spectrum disorders: Stress and support. Exceptional Children, 77(1), 7-36.

Miranda, A., Tárraga, R, Fernández, M. I., Colomer, C., \& Pastor, G. (2015). Parenting stress in families of children with Autism Spectrum Disorder and ADHD. Exceptional Children, 82(1), 81-95. https://doi.org/10.1177/0014402915585479

Neff, K. (2003). Self-compassion: An alternative conceptualization of a healthy attitude toward oneself. Self and Identity, 2(2), 85-101. https://doi.org/10.1080/15298860309032

Neff, K. D. (2003). The development and validation of a scale to measure self-compassion. Self and Identity, 2(3), 223-250. https://doi.org/10.1080/15298860309027

Neff, K. D., \& Faso, D. J. (2014). Self-compassion and well-being in parents of children with autism. Mindfulness, 6(4), 938-947.https://doi.org/10.1007/s12671-014-0359-2

Neff, K. D., \& Germer, C. K. (2012). A pilot study and randomized controlled trial of the mindful selfcompassion program. Journal of Clinical Psychology, 69(1), 28-44. https://doi.org/10.1002/jclp.21923

Patterson, G. (1986). Performance models for antisocial boys. The American Psychologist, 41, 432-444. https://doi.org/10.1037//0003-066X.41.4.432

Phelps, K. W., McCammon, S. L., Wuensch, K. L., \& Golden, J. A. (2009). Enrichment, stress, and growth from parenting an individual with an autism spectrum disorder. Journal of Intellectual and Developmental Disability, 34(2), 133-141. https://doi.org/10.1080/13668250902845236 
Pimentel, M. J., Vieira-Santos, S., Santos, V., \& Vale, M. C. (2011). Mothers of children with attention deficit/hyperactivity disorder: relationship among parenting stress, parental practices and child behaviour. ADHD Attention Deficit and Hyperactivity Disorders, 3(1), 61-68. https://doi.org/10.1007/s12402-011-0053-3

Platt, J. M., Keyes, K. M., McLaughlin, K. A., \& Kaufman, A. S. (2018). Intellectual disability and mental disorders in a US population representative sample of adolescents. Psychological Medicine, 49(6), 952-961. https://doi.org/10.1017/S0033291718001605

Priherdityo, E. (2016, April 7). Indonesia masih gelap tentang autisme. CNN Indonesia. https://www.cnnindonesia.com/gaya-hidup/20160407160237-255-122409/indonesiamasih-gelap-tentang-autisme

Riany, Y. E. (2021). Strategi dan tantangan pengasuhan anak di Indonesia. Rajawali Pers.

Riany, Y. E., Cuskelly, M., \& Meredith, P. (2017). Parenting style and parent-child relationship: A comparative study of Indonesian parents of children with and without Autism Spectrum Disorder (ASD). Journal of Child and Family Studies, 26(12), 3559-3571. https://doi.org/10.1007/s10826-017-0840-3

Riany, Y. E., Meredith, P., \& Cuskelly, M. (2016). Understanding the influence of traditional cultural values on Indonesian parenting. Marriage \& Family Review, 53(3), 207-226. https://doi.org/10.1080/01494929.2016.1157561

Schroeder, V. M., \& Kelley, M. L. (2009). Associations between family environment, parenting practices, and executive functioning of children with and without ADHD. Journal of Child and Family Studies, 18(2), 227-235. https://doi.org/10.1007/s10826-008-9223-0

Simons, R. L., Whitbeck, L. B., Conger, R. D., \& Melby, J. N. (1990). Husband and wife differences in determinants of parenting: A social learning and exchange model of parental behavior. Journal of Marriage and the Family, 52(2), 375. https://doi.org/10.2307/353033

Stayhorn, J. M., \& Weidman, C. S. (1988). A parent practices scale and its relation to parent and child mental health. Journal of the American Academy of Child \& Adolescent Psychiatry, 27(5), 613618. https://doi.org/10.1097/00004583-198809000-00016

Stormshak, E. A., Bierman, K. L., McMahon, R. J., \& Lengua, L. J. (2000). Parenting practices and child disruptive behavior problems in early elementary school. Journal of Clinical Child Psychology, 29(1), 17-29. https://doi.org/10.1207/S15374424jccp2901_3

Straus, M. A. (1989). Manual for the Conflict Tactics Scales (CTS). University of New Hampshire.

Taylor, Z. E., Conger, R. D., Robins, R. W., \& Widaman, K. F. (2015). Parenting practices and perceived social support: Longitudinal relations with the social competence of Mexican-origin children. Journal of Latina/o Psychology, 3(4), 193-208. https://doi.org/10.1037/lat0000038

Tentama, E. (2012). Memahami anak hiperaktif. Universitas Ahmad Dahlan.

Theule, J., Wiener, J., Rogers, M. A., \& Marton, I. (2011). Predicting parenting stress in families of children with ADHD: Parent and contextual factors. Journal of Child and Family Studies, 20(5), 640-647. https://doi.org/10.1007/s10826-010-9439-7

Wijaya, Y. D. (2015). Positive Parenting Program (Triple P) sebagai usaha untuk menurunkan pengasuhan disfungsional pada orangtua yang mempunyai anak berkebutuhan khusus (dengan diagnosa autis dan ADHD). Jurnal Psikologi: Media Ilmiah Psikologi, 13(1), 20-24.

Zimet, G. D., Dahlem, N. W., Zimet, S. G., \& Farley, G. K. (1988). The multidimensional scale of perceived social support. Journal of Personality Assessment, 52(1), 30-41. https://doi.org/10.1207/s15327752jpa5201_2 